\title{
Physiological and oxidative stress responses of four potato clones to aluminum in nutrient solution
}

\author{
Luciane A. Tabaldi ${ }^{1,4}$, Fernando T. Nicoloso ${ }^{1,4 *}$, Gabriel Y. Castro ${ }^{1}$, Denise Cargnelutti ${ }^{2,5}$, Jamile \\ F. Gonçalves ${ }^{1,4}$, Renata Rauber ${ }^{1}$, Etiane C. Skrebsky ${ }^{1,4}$, Maria R.C. Schetinger ${ }^{2,5}$, Vera M. \\ Morsch $^{2,5}$ and Dilson A. Bisognin ${ }^{3,4}$
}

\begin{abstract}
${ }^{1}$ Departamento de Biologia. ${ }^{2}$ Departamento de Química. ${ }^{3}$ Departamento de Fitotecnia. ${ }^{4}$ Programa de Pós-Graduação em Agronomia. ${ }^{5}$ Programa de Pós-Graduação em Bioquímica Toxicológica. Centro de Ciências Naturais e Exatas, Universidade Federal de Santa Maria, 97105-900 Santa Maria, RS, Brasil. *Corresponding author: ftnicoloso@yahoo.com
\end{abstract}

Received: 23 August 2007; Returned for revision: 08 November 2007; Accepted: 03 December 2007

Aluminum toxicity is a serious problem in Brazilian soils and selecting potato clones is an important strategy to produce this crop on these kinds of soils. Potato clones, Macaca, SMIC148-A, Dakota Rose, and Solanum microdontum, were grown in a nutrient solution (pH 4.0) with 0, 50, 100, 150 and $200 \mathrm{mg} \mathrm{Al} \mathrm{L}^{-1}$. After $7 \mathrm{~d}$, Al concentration in both root system and shoot of all clones increased linearly with increasing Al levels. Based on relative root growth, S. microdontum and SMIC148-A were considered Al-tolerant clones, whereas Macaca and Dakota Rose were considered Al-sensitive. Shoot growth in Macaca linearly decreased with increasing Al levels. Root $\mathrm{H}_{2} \mathrm{O}_{2}$ concentration in both Al-sensitive clones increased with increasing Al supply, whereas in Al-tolerant clones it either decreased (SMIC148-A) or demonstrated no alteration (S. microdontum). Shoot $\mathrm{H}_{2} \mathrm{O}_{2}$ concentration increased linearly in Macaca, whereas for Dakota Rose it showed a quadratic relationship with Al levels. On the other hand, shoot $\mathrm{H}_{2} \mathrm{O}_{2}$ concentration in the Al-tolerant clones either demonstrated no alteration (S. microdontum) or presented lower levels (SMIC148-A). Root catalase (CAT) activity in both Al-sensitive clones increased with increasing $\mathrm{Al}$ levels, whereas in Al-tolerant clones it either demonstrated no alteration (SMIC148-A) or presented lower levels (S. microdontum). Shoot CAT activity in the S. microdontum increased curvilinearly with increasing Al levels. In all potato clones, chlorophyll concentration showed a curvilinear response to Al supply, where in Al-sensitive clones it decreased upon addition of $\mathrm{Al}$ exceeding $100 \mathrm{mg} \mathrm{L}^{-1}$, but in SMIC148-A it increased at levels between approximately 100 and $150 \mathrm{mg} \mathrm{L}^{-1}$, and decreased in S. microdontum regardless of the $\mathrm{Al}$ level. Carotenoid concentrations in the Al-sensitive clones were linearly decreased with increasing $\mathrm{Al}$ levels. Aluminum supply caused root lipid peroxidation only in the Al-sensitive clones, whereas in the shoot it increased linearly in the Al-sensitive clones and in S. microdontum it only increased at around $50 \mathrm{mg} \mathrm{L}^{-1}$. Most of root protein oxidation was only observed in the Al-sensitive clones. However, shoot protein oxidation was increased with increasing $\mathrm{Al}$ levels for all potato clones. These results indicate that oxidative stress caused by $\mathrm{Al}$ in potato may harm several components of the cell, mainly in Al-sensitive clones.

Keywords: aluminum toxicity, antioxidative enzymes, growth, oxidative stress, Solanum tuberosum

Respostas fisiológicas e de estresse oxidativo de quarto clones de batata ao alumínio em solução nutritiva: A toxicidade do alumínio é um problema sério em solos brasileiros e a seleção de clones de batata é uma estratégia importante para produzir essa cultura em tais solos. Clones de batata, Macaca, SMIC148-A, Dakota Rose e Solanum microdontum, foram cultivados em solução nutritiva (pH 4.0) com 0, 50, 100, 150 e 200 mg Al L-1 . Após 7 d, o teor de Al em raízes e parte aérea em todos clones aumentou linearmente com o suprimento de Al. Baseado no crescimento relativo da raiz, os clones $S$. microdontum e SMIC148-A foram considerados tolerantes ao Al, enquanto os clones Macaca e Dakota Rose foram considerados sensíveis. O crescimento da parte aérea do clone Macaca diminuiu linearmente com o Al. A concentração 
de $\mathrm{H}_{2} \mathrm{O}_{2}$ nas raízes de ambos os clones sensíveis ao $\mathrm{Al}$ aumentou com o suprimento de $\mathrm{Al}$, enquanto nos clones tolerantes houve decréscimo (SMIC148-A) ou falta de resposta (S. microdontum). A concentração de $\mathrm{H}_{2} \mathrm{O}_{2}$ na parte aérea aumentou linearmente em Macaca, enquanto em Dakota Rose houve uma relação quadrática com os níveis de Al. Por outro lado, nos clones tolerantes ao $\mathrm{Al}$ a concentração de $\mathrm{H}_{2} \mathrm{O}_{2}$ não foi alterada (S. microdontum) ou foi reduzida (SMIC148-A). A atividade da catalase (CAT) nas raízes de ambos clones sensíveis ao Al aumentou com o suprimento de $\mathrm{Al}$, enquanto nos clones tolerantes não houve alteração (SMIC148-A) ou, então, redução (S. microdontum). Na parte aérea, a atividade da CAT em S. microdontum aumentou com o suprimento de Al. Em todos clones de batata, a concentração de clorofila variou curvilinearmente em relação ao suprimento de Al; nos clones sensíveis, a concentração de clorofila diminuiu pela adição de Al em níveis acima de $100 \mathrm{mg} \mathrm{L}^{-1}$, porém em SMIC148-A houve aumento na presença de Al (na faixa próxima a 100 e $150 \mathrm{mg} \mathrm{L}^{-1}$ ) e diminuição em S. microdontum, independentemente do tratamento de Al. A concentração de carotenóides nos clones sensíveis ao Al diminuiu linearmente, em resposta ao Al. O Al aumentou a peroxidação lipídica em raízes dos clones sensíveis, enquanto na parte aérea houve aumento linear nesses clones e também em S. microdontum (próximo a $50 \mathrm{mg} \mathrm{Al} \mathrm{L}^{-1}$ ). A oxidação protéica foi observada principalmente nas raízes dos clones sensíveis ao alumínio. Entretanto, foi observada oxidação protéica na parte aérea de todos clones de batata, em resposta ao Al. Estes resultados indicam que o estresse oxidativo causado por $\mathrm{Al}$ em batata pode prejudicar vários componentes celulares, principalmente nos clones sensíveis ao metal.

Palavras-chave: crescimento, enzimas antioxidativas, estresse oxidativo, Solanum tuberosum, toxicidade de Al

\section{INTRODUCTION}

Most tropical soils present an acid characteristic that decreases nutrient availability and increases aluminum (Al) toxicity, affecting plant growth and development (Marschner, 1991). Aluminum is the most abundant metal and the third most common element in the earth's crust. Aluminum toxicity is considered a major abiotic stress factor in low $\mathrm{pH}$ soils. Aluminum stress impairs root growth, decreasing the absorption, transport and use of several nutrients such as $\mathrm{P}, \mathrm{Ca}, \mathrm{Mg}, \mathrm{S}, \mathrm{Fe}$ and $\mathrm{Mn}$ and diminishing biomass production (Brondani and Paiva, 1996).

The initial and most evident symptom of Al-toxicity is a rapid inhibition of root elongation (Dipierro et al., 2005), which can occur within minutes after exposing roots to $\mathrm{Al}$, with less marked effects on shoot development. Severe Al-toxicity reduces and damages the root system, causing plant drought susceptibility and mineral nutrient deficiency. The principal sites of Al-toxicity are the actively dividing and expanding cells of the root apex (Ryan et al., 1993). Aluminum can rapidly enter into the cytoplasm (Lazof et al., 1994), but it is still unknown whether the primary site(s) of toxicity is external (interactions with the cell wall or external face of plasma membrane) or internal (affecting cytoplasmic functions or activities in internal membranes/compartments). After prolonged exposure (e.g. 12 h), Al can affect many physiological processes either directly or indirectly (Kochian, 1995). Genetic variability to Al-tolerance exists among and within plant species.

Many environmental stresses induce the formation of reactive oxygen species (ROS) in plant cells (Schützendübel and Polle, 2002). Aluminum toxicity in plants is a well-known example of such environmental stress (Kochian, 1995; Ma et al., 2001). Under normal conditions, the production and destruction of these radicals is regulated by cell metabolism. To prevent cellular compartments from the damaging effects of ROS, organisms have evolved multiple detoxification mechanisms, including synthesis of antioxidant molecules (ascorbic acid, glutathione and carotenoids) and enzyme systems such as superoxide dismutases (SOD, E.C.1.15.1.1), ascorbate peroxidase (APX, E.C.1.11.1.11) and catalase (CAT, E.C.1.11.1.6). These ROS can attack membranes, proteins and nucleic acids causing lipid peroxidation, protein denaturation and DNA mutation (Schützendübel and Polle, 2002). Oxidative stress is probably an important component of plant response to Al-toxicity.

It has been suggested that $\mathrm{Al}^{3+}$, the most toxic of the soluble forms of $\mathrm{Al}$ (Parker et al., 1988), induces oxidative stress, since this ion is involved in various processes, including an increase in SOD activity and lipid peroxidation in soybeans (Cakmak and Horst, 1991), peas 
(Yamamoto et al., 2001) and tobacco plants (Ikegawa et al., 2000). Moreover, alterations in the expression of various genes induced by $\mathrm{Al}$ in arabidopsis (Richards et al., 1998), tobacco (Ezaki et al., 2000) and wheat (Snowden and Gardner, 1993) have been reported.

Potatos are grown worldwide under a wider range of altitudes, latitudes, and climatic conditions than any other major food crop - from sea level to over $4000 \mathrm{~m}$ elevation. No other crop can match the potato in its production of food energy and food value per unit area (Sieczka and Thornton, 1993). The widely cultivated potato (Solanum tuberosum subsp. tuberosum) is very sensitive to abiotic stresses, whereas several wild or primitive cultivated species of different ploidy levels are well adapted to growth under unfavorable conditions such as drought, cold, salinity and high irradiation ( $\mathrm{Li}$ and Fennell, 1985). The fact that the Solanum species possess genetic variation for abiotic stresses is not only interesting for potato breeding but also as a model plant to study other aspects of physiological resistance. An appropriate approach to evaluate the $\mathrm{Al}$ stress response is a genotype evaluation in nutrient solution under controlled conditions (Schmohl et al., 2000; Jorge et al., 2001; Boscolo et al., 2003). In spite of the importance of the potato, there is no report in the literature on its antioxidant system under Al-stress conditions. The antioxidant system is responsible for scavenging excess free radicals caused by environmental stresses. Studying the major components of the antioxidant system under $\mathrm{Al}$ stress, it is possible to ascertain whether $\mathrm{Al}$ induces oxidative stress, and whether it is involved in Altolerance mechanisms.

The objective of the present study was, therefore, to investigate and compare some physiological and oxidative stress responses of four potato clones, Macaca, Solanum microdontum, SMIC148-A and Dakota Rose, exposed to $\mathrm{Al}$ in nutrient solution.

\section{MATERIAL AND METHODS}

Plant materials and growth conditions: Three adapted $(2 \mathrm{n}=4 \mathrm{x}=48)$ clones (Macaca, SMIC148-A and Dakota Rose) and one wild species $(2 \mathrm{n}=2 \mathrm{x}=24)$ clone (PI595511-5/ S. microdontum) were evaluated. The S. microdontum clone was identified as highly resistant to Phytophora infestans (Bisognin et al., 2005) and has been used in our breeding program. This clone will be referred to as $S$. microdontum. Tissue culture plantlets were obtained from the Potato Breeding and Genetics Program, Federal University of Santa Maria, Brazil. Nodal segments $(1.0 \mathrm{~cm}$ long) were micropropagated in MS medium (Murashige and Skoog, 1962), supplemented with $30 \mathrm{~g} \mathrm{~L}^{-1}$ of sucrose, $0.1 \mathrm{~g} \mathrm{~L}^{-1}$ of myo-inositol and $6 \mathrm{~g} \mathrm{~L}^{-1}$ of agar. Twenty-dayold plantlets from in vitro culture were transferred into plastic boxes $(10 \mathrm{~L})$ filled with aerated full nutrient solution of low ionic strength. The nutrient solution had the following composition (in $\mu \mathrm{M}$ ): 6090.5 of N; 974.3 of Mg; 5229.5 of Cl; 2679.2 of K; 2436.2 of Ca; 359.9 of S; 0.47 of $\mathrm{Cu} ; 2.00$ of Mn; 1.99 of $\mathrm{Zn} ; 0.17$ of Ni; 24.97 of B; 0.52 of $\mathrm{Mo} ; 47.99$ of $\mathrm{Fe}\left(\mathrm{FeSO}_{4} / \mathrm{Na}-\mathrm{EDTA}\right)$. Treatments consisted of the addition of $0,50,100,150$ or $200 \mathrm{mg} \mathrm{L}^{-1}$ of Al as $\mathrm{AlCl}_{3} \cdot 6 \mathrm{H}_{2} \mathrm{O}$. The solution $\mathrm{pH}$ was adjusted daily to $4.0 \pm$ 0.1 by titration with $\mathrm{HCl}$ or $\mathrm{NaOH}$ solutions of $0.1 \mathrm{M}$. Both in vitro and ex vitro cultured plants were grown in a growth chamber at $25 \pm 2^{\circ} \mathrm{C}$ on a 16/8-h light/dark cycle with $35 \mu \mathrm{mol} \mathrm{m}{ }^{-2} \mathrm{~s}^{-1}$ of irradiance. Aluminum-treated plantlets remained in each treatment for $7 \mathrm{~d}$. At harvest, the plants were divided into shoot and roots. Roots were rinsed twice with distilled water. Subsequently, growth and biochemical parameters were determined. Three replicates with nine seedlings were made for each treatment.

Aluminum determination: After Al treatment, samples (roots and shoot) were separated and washed in deionized water twice and dried at $60^{\circ} \mathrm{C}$ until reaching a constant weight. The dried tissues were weighed and ground into a fine powder before nitric-percloric digestion. Aluminum concentrations were determined by atomic absorption spectrometry. A standard calibration curve was prepared for the $0-200 \mathrm{mg} \mathrm{L}^{-1} \mathrm{Al}$ concentration range.

Growth parameters: To access different responses to $\mathrm{Al}$ sensitivity the relative root growth (RRG) of four clones was determined. Before $\mathrm{Al}$ treatment, the length of the main root of each plantlet was measured and recorded. Afterwards, the plantlet returned to the nutrient solution. At the end of the experiment ( $7 \mathrm{~d}$ after Al application), the length of the main root was measured again. The RRG was calculated by dividing the root growth of each seedling under a given treatment by the mean root growth of all 
plantlets grown in the control solution (Jorge et al., 2001). Shoot length and total number of nodal segments per plantlet were also determined.

Determination of hydrogen peroxide: The $\mathrm{H}_{2} \mathrm{O}_{2}$ concentration was determined according to Loreto and Velikova (2001). Approximately $0.1 \mathrm{~g}$ of both roots and shoots was homogenized at $4^{\circ} \mathrm{C}$ in $2 \mathrm{~mL}$ of $0.1 \%$ trichloroacetic acid (TCA) (w/v). The homogenate was centrifuged at $12000 \mathrm{xg}$ for $15 \mathrm{~min}$ at $4^{\circ} \mathrm{C}$. Then, $0.5 \mathrm{~mL}$ of the supernatant was added to $0.5 \mathrm{~mL}$ of $10 \mathrm{mM} \mathrm{K}$ phosphate buffer ( $\mathrm{pH} 7.0$ ) and $1 \mathrm{~mL}$ of $1 \mathrm{M} \mathrm{KI}$. The $\mathrm{H}_{2} \mathrm{O}_{2}$ concentration of the supernatant was evaluated by comparing its absorbance at $390 \mathrm{~nm}$ with a standard calibration curve. Hydrogen peroxide concentration was expressed as $\mu \mathrm{mol} \mathrm{g}{ }^{-1} \mathrm{FW}$.

Catalase assay: Catalase activity was assayed following the modified Aebi (1984) method. Fresh roots and shoot samples ( $1 \mathrm{~g}$ ) were homogenized in $5 \mathrm{~mL}$ of $50 \mathrm{mM} \mathrm{K-}$ phosphate buffer (pH 7.0), $10 \mathrm{~g} \mathrm{~L}^{-1} \mathrm{PVP}, 0.2 \mathrm{mM}$ EDTA and $10 \mathrm{~mL} \mathrm{~L}^{-1}$ Triton X-100. The homogenate was centrifuged at $12000 \mathrm{x} \mathrm{g}$ for $20 \mathrm{~min}$ at $4^{\circ} \mathrm{C}$ and the supernatant was used for enzyme assay. Activity of CAT was determined by measuring the decrease in absorbance at $240 \mathrm{~nm}$ of a reaction mixture with a final volume of $2 \mathrm{~mL}$ containing 15 $\mathrm{mM} \mathrm{H} \mathrm{O}_{2}$ in K-phosphate buffer ( $\mathrm{pH} 7.0$ ) and $30 \mu \mathrm{L}$

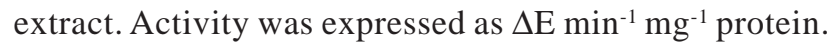

Chlorophyll and carotenoid determination: Chlorophyll and carotenoids were extracted following the method of Hiscox and Israelstam (1979) and estimated with the help of Arnon's formulae (Arnon, 1949). Fresh leaves (0.1 g) were incubated at $65^{\circ} \mathrm{C}$ in dimethylsulfoxide (DMSO) until pigments were completely bleached. Absorbance of the solution was then measured at 663 and $645 \mathrm{~nm}$ for chlorophyll and $470 \mathrm{~nm}$ for carotenoids. Chlorophyll and carotenoid concentrations were expressed as $\mu \mathrm{g} \mathrm{g}^{-1} \mathrm{FW}$ and $\mathrm{mg} \mathrm{g}^{-1} \mathrm{FW}$, respectively.

Estimation of lipid peroxides: The degree of lipid peroxidation was estimated following the method ElMoshaty et al. (1993). Fresh roots and shoot samples of $0.1 \mathrm{~g}$ were homogenized in $20 \mathrm{~mL}$ of $0.2 \mathrm{M}$ citratephosphate buffer ( $\mathrm{pH}$ 6.5) containing $0.5 \%$ Triton X-100, using mortar and pestle. The homogenate was filtered with two paper layers and centrifuged for $15 \mathrm{~min}$ at 20,000 $\mathrm{x} g$. One milliliter of the supernatant fraction was added to an equal volume of $20 \%(\mathrm{w} / \mathrm{v})$ TCA containing $0.5 \%(\mathrm{w} / \mathrm{v})$ of thiobarbituric acid (TBA). The mixture was heated at $95^{\circ} \mathrm{C}$ for $40 \mathrm{~min}$ and then quickly cooled in an ice bath for $15 \mathrm{~min}$, and centrifuged at $10,000 \times \mathrm{g}$ for $15 \mathrm{~min}$. The absorbance of the supernatant at $532 \mathrm{~nm}$ was read and corrected for unspecific turbidity by subtracting the value of the absorbance at $600 \mathrm{~nm}$. The lipid peroxides were expressed as nmol MDA $\mathrm{mg}^{-1}$ protein, by using an extinction coefficient of $155 \mathrm{~L} \mathrm{mmol}^{-1} \mathrm{~cm}^{-1}$.

Protein oxidation: Samples of roots and shoot (1 g) were homogenized with $25 \mathrm{mM}$ K-phosphate buffer ( $\mathrm{pH} 7.0$ ) containing $10 \mathrm{~mL} \mathrm{~L}^{-1}$ Triton $\mathrm{X}-100$, at a proportion of 1:2 (w/v) (Levine et al., 1990). After the homogenate was centrifuged at $15,000 \mathrm{x} g$ for $10 \mathrm{~min}$ at $4^{\circ} \mathrm{C}$, the supernatant was used for immediate determination of protein oxidation, which was expressed as nmol carbonyl $\mathrm{mg}^{-1}$ protein.

Protein determination: In all the enzyme preparations, protein was determined following Bradford, (1976) using BSA for constructing the standard curves.

Statistical analysis: All data were analyzed by ANOVA procedures. The effects of $\mathrm{Al}$ on growth and biochemical parameters in potato plantlets were quantified using regression analysis with the SOC statistic package (Software Científico: NTIA/EMBRAPA). Coefficients were included in a regression equation when their values were significant $(P<0.05)$.

\section{RESULTS}

Aluminum concentration: Regression analysis showed that the concentration of $\mathrm{Al}$ in both the roots and shoots of all clones studied increased linearly with increasing $\mathrm{Al}$ levels, and the increase in tissue $\mathrm{Al}$ was much steeper for Macaca and SMIC148-A (Figure 1A,B). Aluminum accumulated more in roots than in shoot (on average of 3.9-, 2.8-, 3.6-, and 3.7-fold greater in roots than in shoot, respectively in Macaca, S. microdontum, SMIC148-A and Dakota Rose clones). The maximum concentration of $\mathrm{Al}$ in roots and shoot was 49,300 and $17,900 \mathrm{mg} \mathrm{kg}^{-1}$, as respectively found in Dakota Rose clone at $200 \mathrm{mg} \mathrm{Al} \mathrm{L}^{-1}$. 
In Macaca and SMIC148-A clones, $\mathrm{Al}$ concentration was lower at levels above $50 \mathrm{mg} \mathrm{L}^{-1}$ when compared with Dakota Rose and S. microdontum clones (Figure 1A,B).

Growth analysis: The response of root growth in the Alsensitive clones (Macaca and Dakota Rose) to Al levels was linear and negative (Figure 2A), whereas in the Altolerant clones there was no alteration. At $200 \mathrm{mg} \mathrm{Al} \mathrm{L}^{-1}$, root growth of Macaca and Dakota Rose clones decreased by about 95 and $70 \%$, respectively, when compared to the control. Therefore, Macaca and Dakota Rose were classified as Al-sensitive clones, and $S$. microdontum and SMIC148-A as Al-tolerant clones.

Aluminum negatively affected shoot length only in Macaca plantlets (Figure 2B). At $200 \mathrm{mg} \mathrm{Al} \mathrm{L}^{-1}$, shoot length was decreased by $74 \%$ when compared to the control. Also, Al treatments linearly reduced the total number of nodal segments in Macaca, SMIC148-A and Dakota Rose clones (Figure 2C).

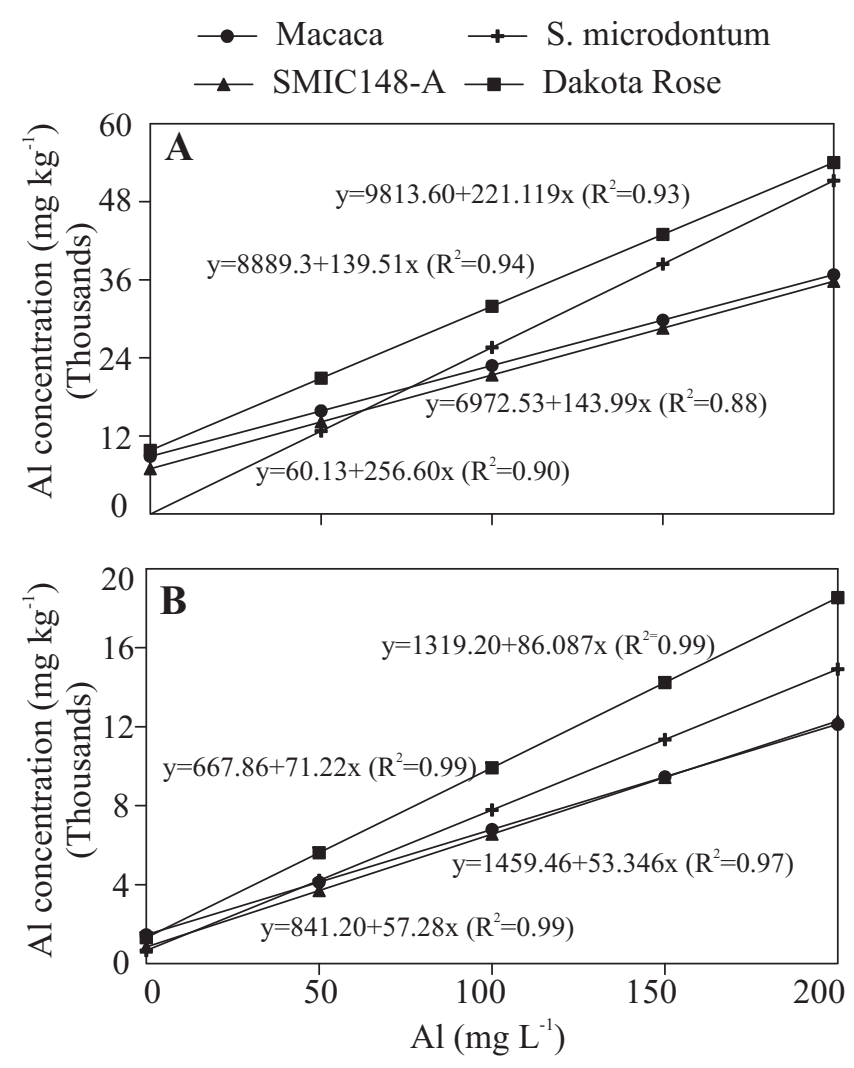

Figure 1. Aluminum content in roots (A) and shoot (B) of potato plants (Macaca, S. microdontum, SMIC148-A and Dakota Rose clones) submitted to increasing Al levels for $7 \mathrm{~d}$. Each point is the mean of three replicates.
Catalase activity and hydrogen peroxide concentration: Root $\mathrm{H}_{2} \mathrm{O}_{2}$ concentration in the two Al-sensitive clones increased with increasing $\mathrm{Al}$ levels, whereas in the Al-tolerant clones it either decreased (SMIC148-A) or did not demonstrate any alteration (S. microdontum) (Figure 3A). Shoot $\mathrm{H}_{2} \mathrm{O}_{2}$ concentration increased linearly in Macaca, whereas for Dakota Rose it showed a quadratic relationship with $\mathrm{Al}$ levels. On the other hand, $\mathrm{H}_{2} \mathrm{O}_{2}$ concentration in the Al-tolerant clones either did
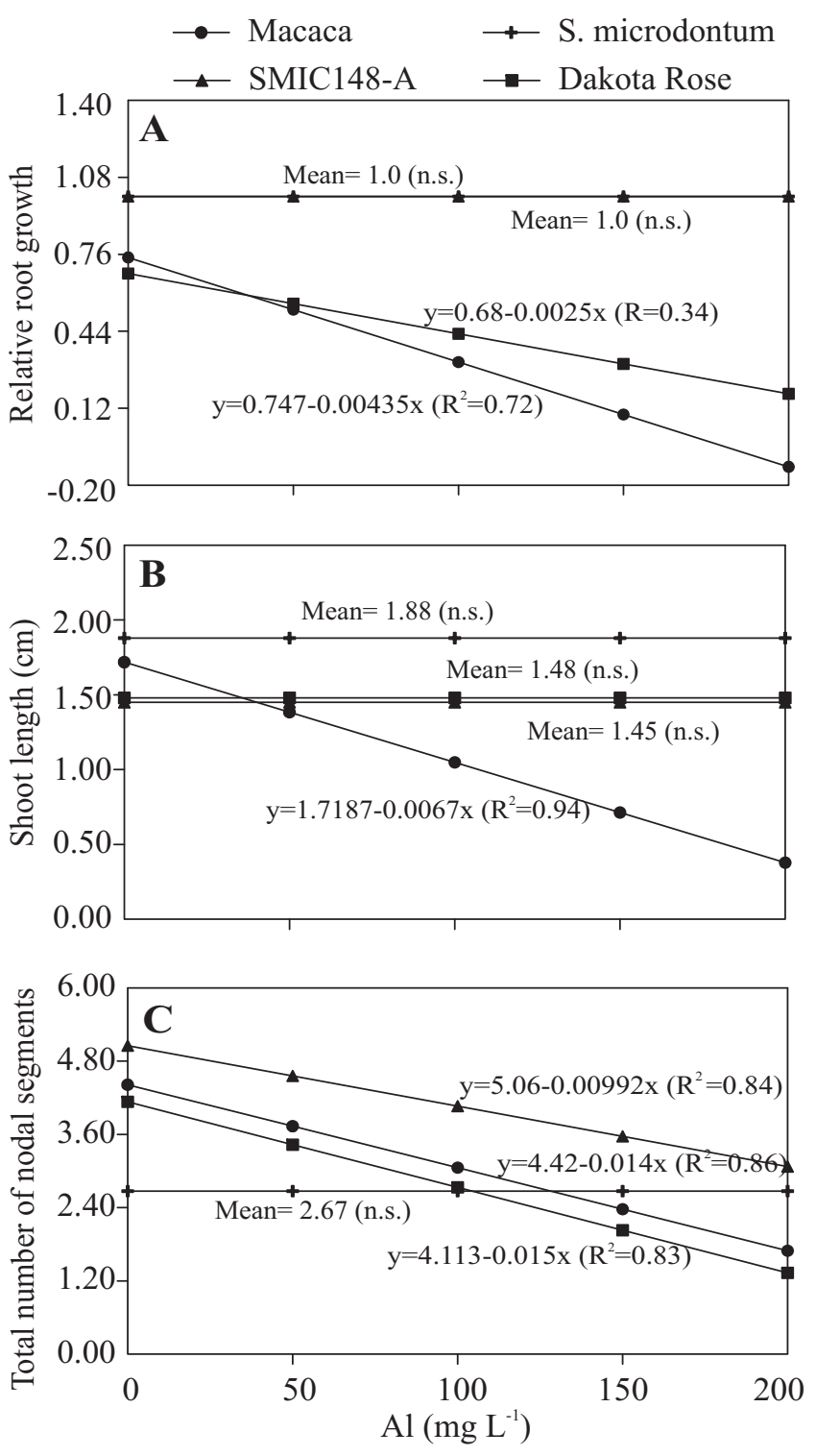

Figure 2. Relative root growth (A), shoot length (B) and total number of nodal segments (C) in potato plants (Macaca, S. microdontum, SMIC148-A and Dakota Rose clones) submitted to increasing $\mathrm{Al}$ levels for $7 \mathrm{~d}$. Each point is the mean of three replicates. n.s. = not significant. 
not demonstrate any alteration (S. microdontum) or presented lower levels (SMIC148-A) (Figure 3B). Root CAT activity increased curvilinearly with increasing Al levels in Macaca, whereas in Dakota Rose it decreased at ca. $50 \mathrm{mg} \mathrm{L}^{-1}$ and increased at levels exceeding $100 \mathrm{mg} \mathrm{L}^{-}$ ${ }^{1}$ (Figure 3C). Root CAT activity in the Al-tolerant clones either did not demonstrate any alteration (SMIC148-A) or presented lower levels (S. microdontum). Shoot CAT activity was only altered in S. microdontum, where it increased curvilinearly with increasing Al levels exceeding $100 \mathrm{mg} \mathrm{L}^{-1}$ (Figure 3D).

Chlorophyll and carotenoid levels: In all potato clones, chlorophyll concentration showed a curvilinear response to Al supply, where it increased at $c a .50 \mathrm{mg} \mathrm{Al} \mathrm{L}^{-1}$ and decreased at levels exceeding $100 \mathrm{mg} \mathrm{L}^{-1}$ in the Alsensitive clones. However, in SMIC148-A, it increased between approximately 100 and $150 \mathrm{mg} \mathrm{L}^{-1}$, and in $S$. microdontum it decreased regardless of the Al level (Figure 4A). Carotenoid concentrations in the Alsensitive clones linearly decreased with increasing $\mathrm{Al}$ levels, whereas in the Al-tolerant clones there was no alteration (Figure 4B).

Lipid peroxidation and protein oxidation: Concentration of MDA in roots and shoot of both Macaca and Dakota Rose increased linearly with increasing Al levels, indicating enhanced lipid peroxidation for these Alsensitive clones (Figure 5A,B). In Macaca and Dakota Rose, the increase of lipid peroxidation in roots was of $c a$. $55 \%$ and $73 \%$, respectively, and in the shoot it was of about $72 \%$ and $149 \%$, respectively. Interestingly, the basal level of lipid peroxidation both in roots and shoot of S. microdontum (Al-tolerant clone) was significantly
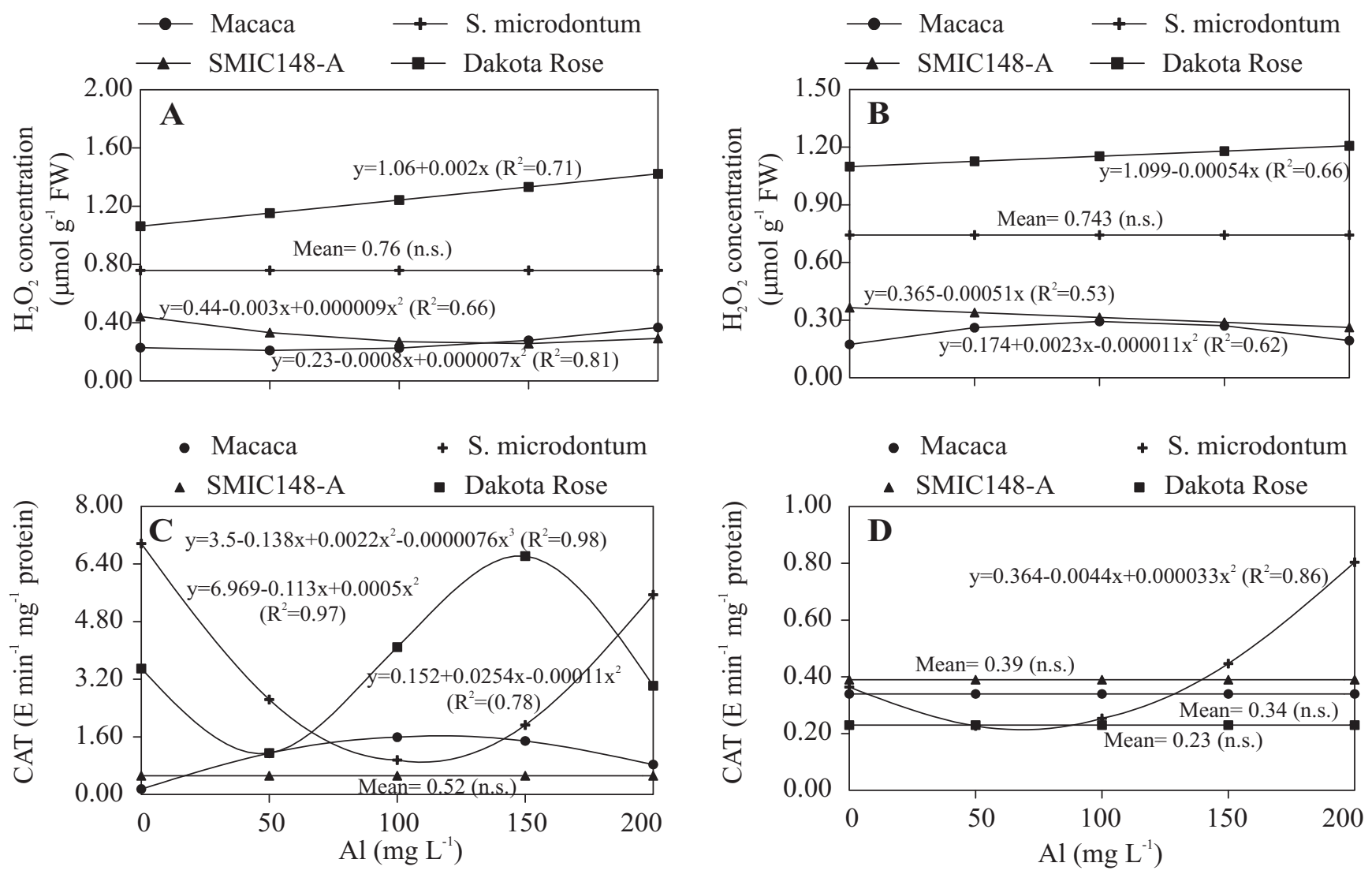

Figure 3. Concentration of $\mathrm{H}_{2} \mathrm{O}_{2}$ in roots (A) and shoot (B) and catalase activity of roots (C) and shoot (D) in potato plants (Macaca, S. microdontum, SMIC148-A and Dakota Rose clones) submitted to increasing Al levels for 7 d. Each point is the mean of three replicates. n.s. = not significant. 


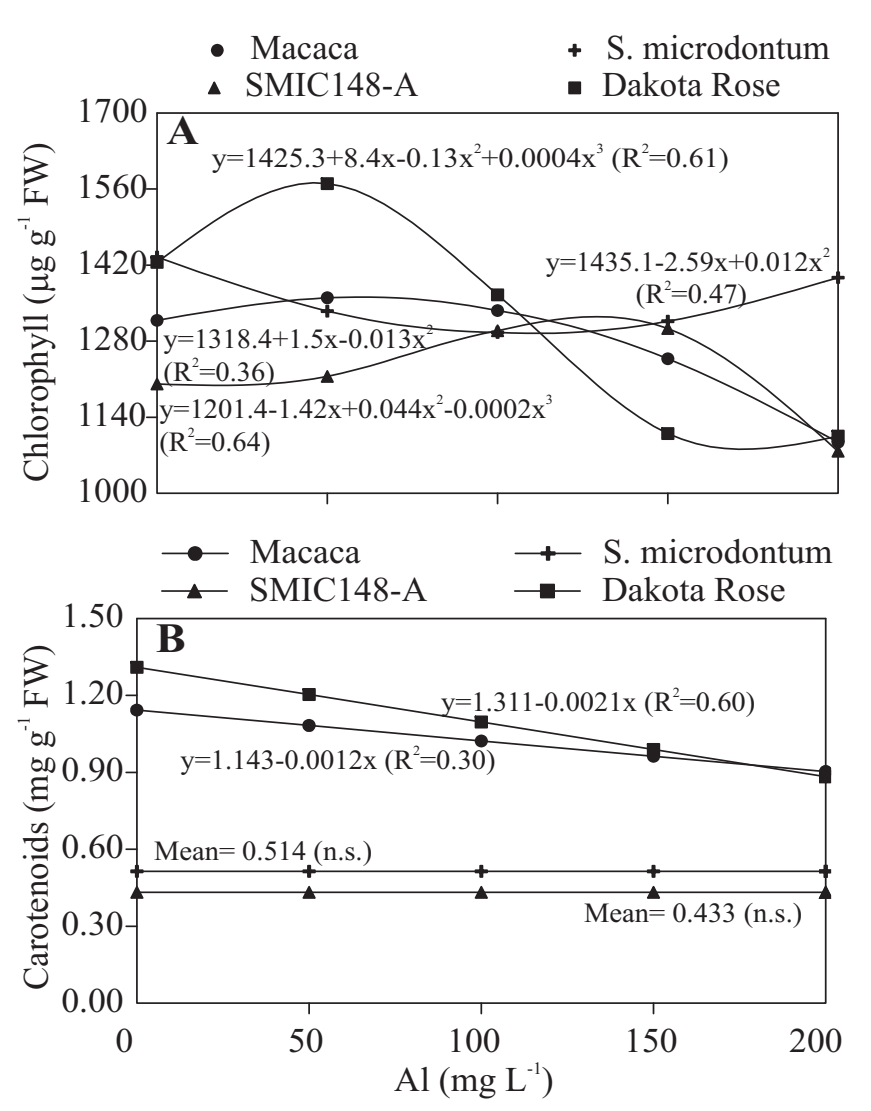

Figure 4. Chlorophyll (A) and carotenoid (B) concentrations in potato plants (Macaca, S. microdontum, SMIC148-A and Dakota Rose clones) submitted to increasing $\mathrm{Al}$ levels for $7 \mathrm{~d}$. Each point is the mean of three replicates. n.s. $=$ not significant.

higher than that of the others. In spite of this, only at lower Al levels did an increase in lipid peroxidation occur (65\%) in the shoot of this clone (Figure 5B).

The carbonyl concentrations in the roots of Alsensitive clones increased linearly with increasing $\mathrm{Al}$ levels, while in the Al-tolerant clones there was a curvilinear response in which SMIC148-A presented increased carbonyl concentrations at levels exceeding $100 \mathrm{mg} \mathrm{L}^{-1}$ and, in contrast, S. microdontum presented a decline in the same $\mathrm{Al}$ range (Figure $5 \mathrm{C}$ ). In the shoot, an increase in protein oxidation occurred for all clones except in the Macaca clone, where it decreased at levels below $150 \mathrm{mg} \mathrm{L}^{-1}$ (Figure 5D). In SMIC148-A and Dakota Rose clones, Al caused a linear increase in carbonyl concentrations, whilst in the $S$. microdontum clones the carbonyl concentrations increased curvelinearly with increasing Al levels.

\section{DISCUSSION}

In the present study, the significant, variant reduction of root growth in potato clones exposed to $\mathrm{Al}$ suggests a distinct physiological sensitivity to Al stress. The phytotoxic effects of Al to the root system, in turn, can cause susceptibility to drought stress and mineral nutrient deficiencies (Degenhardt et al., 1998). This, consequently, might negatively affect growth and development of Al-sensitive plants. Since Al also induced root damage, and roots are the main site of cytokinin synthesis, the reduction in shoot length may therefore be a consequence of impaired cell division in the root meristem (Meriga et al., 2004). Since Al primarily affects the root tips, effects on shoot development may be expressed only at later stages as a result of altered water and nutrient uptake as well as phytohormone production (Collet and Horst, 2001).

Nutrient solutions used as a substrate contain divalent cations which can compete with $\mathrm{Al}$ and influence their availability for plant uptake. Yet, the high Al concentrations of the nutrient solution overcame these limiting factors, since Al concentrations in root tissues showed a significant 3.5-fold increase between Al levels of 0 and $200 \mathrm{mg} \mathrm{L}^{-1}$. Almost all the adsorbed/precipitated $\mathrm{Al}$ on the roots' outer surface and in root cortical cells is not removed after washing with water. Thus, as roots were only washed with deionized water before Al analysis, the values obtained for $\mathrm{Al}$ concentrations are related to both absorbed and adsorbed mechanisms. The sharp increase in root $\mathrm{Al}$ concentrations was closely related to the level of $\mathrm{Al}$ in the nutrient solution, as has been reported elsewhere (Lidon et al., 1999). Moreover, the quite high $\mathrm{Al}$ concentration measured in root tissues in the control was related to a direct uptake from the water/tray substrate. Root $\mathrm{Al}$ concentrations for the $\mathrm{Al}$ treatments were mostly associated with an increase in the level of $\mathrm{Al}$ in the nutrient solution. Accumulation of $\mathrm{Al}$ was lower in the shoot, which indicates that the absorbed Al was mostly retained in root tissues.

A common feature of several stresses, including Altoxicity, is the perturbation of cell redox homeostasis, enhancing ROS production, which is generally considered harmful to plant cells (Richards et al., 1998). Studies on Al-toxicity in roots suggest that the production of ROS may significantly contribute to Al- 

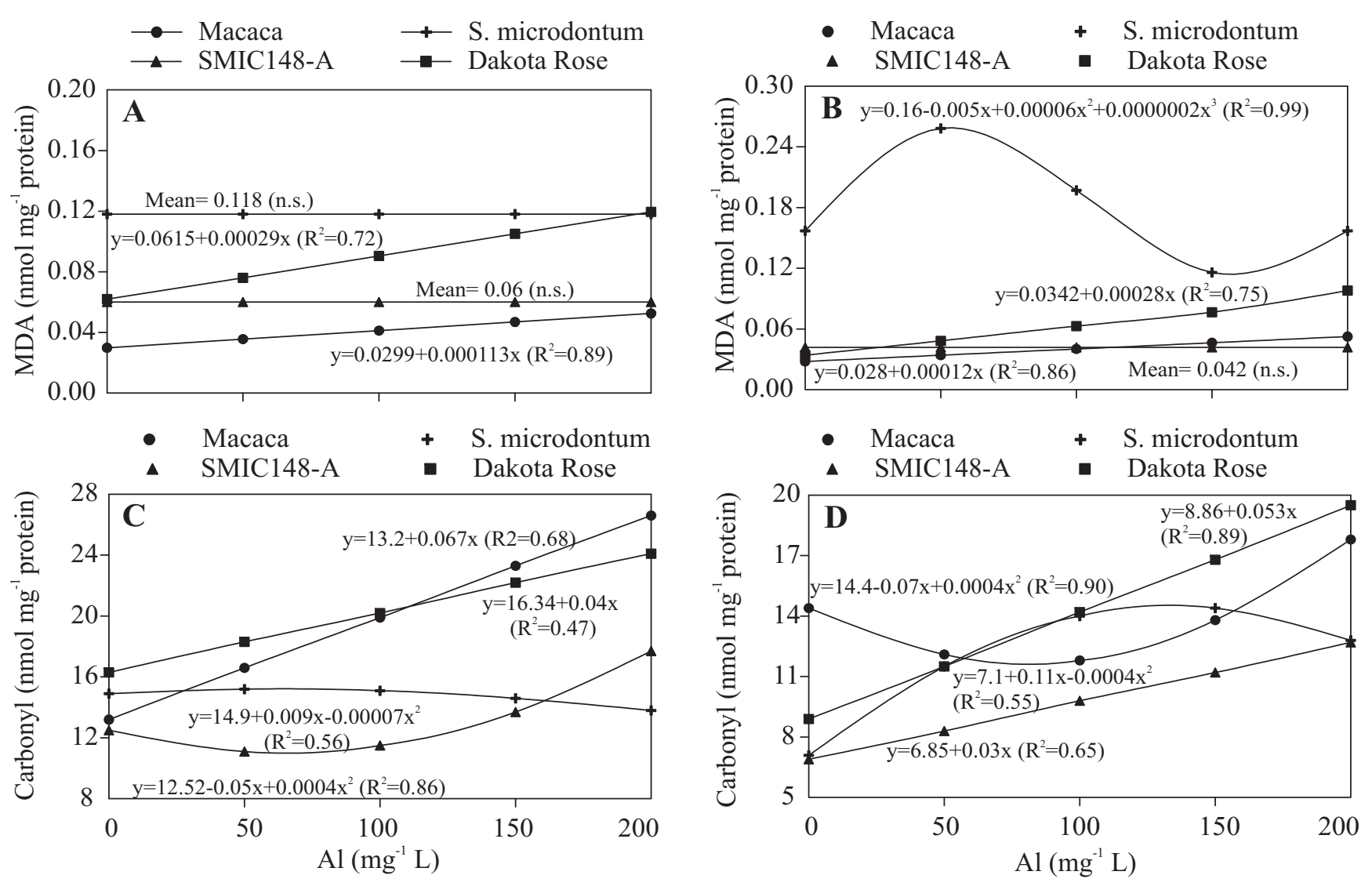

Figure 5. Lipid peroxides in roots (A) and shoot $(\mathbf{B})$ and protein carbonyl in roots (C) and shoot (D) in potato plants (Macaca, S. microdontum, SMIC148-A and Dakota Rose clones) submitted to increasing Al levels for $7 \mathrm{~d}$. Each point is the mean of three replicates. n.s. = not significant.

induced inhibition of root elongation (Tamás et al., 2004). Furthermore, several reports have shown that Al stress can increase the production of ROS, and activate several oxidative enzymes in plant and animal cells (Cakmak and Horst, 1991). Thus, oxidative stress is possibly an important component of Al-toxicity plant responses.

In the present study, $\mathrm{Al}$ stress increased $\mathrm{H}_{2} \mathrm{O}_{2}$ concentration in roots and shoot of both Al-sensitive clones. Elevated $\mathrm{H}_{2} \mathrm{O}_{2}$ production due to $\mathrm{Al}$ has also been observed in barley (Simonovicová et al., 2004), wheat (Darkó et al., 2004) and pumpkin roots (Dipierro et al., 2005). Tamás et al. (2004) also reported elevated $\mathrm{H}_{2} \mathrm{O}_{2}$ production in intact germinating barley seeds during $\mathrm{Al}$ stress. In relation to roots and shoot of Al-tolerant clones, in the SMIC148-A clone reduced $\mathrm{H}_{2} \mathrm{O}_{2}$ concentration was observed with increasing Al levels. This decline of $\mathrm{H}_{2} \mathrm{O}_{2}$ concentration might be due to the scavenging action of the antioxidant system. It can be suggested that Al treatment mainly induced an oxidative burst in both roots and shoot of the Al-sensitive clones, where the antioxidant system was not able to protect these clones from Al toxicity.

Among the enzymatic systems considered to play an important role in the cellular defense strategy against oxidative stress, CAT plays a pivotal role as it decomposes $\mathrm{H}_{2} \mathrm{O}_{2}$ to water and $\mathrm{O}_{2}$. Interestingly, the greater CAT activity in roots than in shoot might indicate higher oxidative stress in roots. In fact, the marked increase of CAT activity in the roots with increasing $\mathrm{Al}$ levels in Macaca and Dakota Rose clones may indicate enhanced production of ROS under an excess of Al. In contrast, at lower levels of Al exposure, CAT activity was inhibited in roots of S. microdontum and Dakota Rose clones. This lower activity in Al-stressed plants is suggestive of a possible delay in removal of $\mathrm{H}_{2} \mathrm{O}_{2}$ and toxic peroxides mediated by CAT and in turn an 
enhancement in the free radical mediated lipid peroxidation under Al-toxicity (Shi et al., 2006). Aluminum increased the activity of CAT in the shoot only in the $S$. microdontum clone at higher $\mathrm{Al}$ concentrations. This enhanced activity seems to be related to increased oxidative stress tolerance (Allen, 1995).

As a visible symptom, the reduced chlorophyll concentration can be used to monitor $\mathrm{Al}$ induced damage in green leaves. In the present study, the reduction in chlorophyll concentration observed for Macaca, S. microdontum and Dakota Rose clones indicates oxidative damage induced by $\mathrm{Al}$ exposure, possibly due to the inhibition of aminolevulinic acid dehydratase, an important enzyme in chlorophyll biosynthesis (Pereira et al., 2006). Carotenoid concentration decreased in Macaca and Dakota Rose (Al-sensitive clones). Although the principal recognized role of carotenoids is to act as photoreceptive antenna pigment for photosynthesis, collecting wavelengths of light that are not absorbed by chlorophylls, their protective function against oxidative damage has also been recognized for several decades (Larson, 1988). Perhaps the most important function of carotenoid is the dissipation of excess energy of excited chlorophyll and the elimination of ROS (Lawlor, 2001).

Lipid peroxidation is a metabolic process that can occur under normal aerobic conditions and is one of the most investigated ROS effects on membrane structure and function (Blokhina et al., 2003). It is widely reported that ROS bring about peroxidation of membrane lipids leading to membrane damage. Since cell membranes are the first targets of many plant stresses, the maintenance of their integrity and stability under stress conditions is a major component of $\mathrm{Al}$ tolerance in plants. In the present study, MDA concentration in both roots and shoot was significantly increased with increasing Al levels in the two Al-sensitive clones, indicating enhanced lipid peroxidation for these clones and, therefore, the presence of poisoning ROS. In S. microdontum (Al-tolerant clone), an increased in shoot lipid peroxidation occurred only at Al levels of approximately $50 \mathrm{mg} \mathrm{L}^{-1}$, indicating that the active stress was lower and growth inhibition was smaller. These results also indicate that the antioxidative system in Al-tolerant clones was more efficient to protect the membrane lipids from $\mathrm{Al}$ stress. Several studies have shown increased lipid peroxidation in plants exposed to Al. In wheat, the increase of MDA concentration in the
Al-sensitive cultivar was greater than in Al-tolerant cultivar (Dong et al., 2002). Yamamoto et al. (2001) showed the induction of lipid peroxidation in pea plants after $4 \mathrm{~h}$ of exposure to $\mathrm{Al}^{3+}$. Cakmak and Horst (1991) also observed an increase in lipid peroxidation of a sensitive soybean cultivar after $24 \mathrm{~h}$ of treatment. Basu et al. (2001) found a correlation between decreased lipid peroxidation and increased resistance to $\mathrm{Al}$ in Brassica napus.

The possible connection between $\mathrm{Al}$ stress and oxidative stress had also been previously suggested by Cakmak and Horst (1991) based upon the fact that the Alinduced inhibition of root elongation was correlated with enhanced lipid peroxidation. The interpretation of these findings was that the primary effects of $\mathrm{Al}$ could be the induction of free radical generation and related alterations in the membrane structure. Further evidence corroborating the relation between $\mathrm{Al}$ stress and oxidative stress in plants has recently been obtained with transgenic arabidopsis plants (Ezaki et al., 2000).

In the present study, protein damage due to increased stress suggests Al-induced formation of ROS. Halliwell and Gutteridge (1999) suggested that the oxidation of proteins to form carbonyls occurs via the hydroxyl radical, since neither $\mathrm{H}_{2} \mathrm{O}_{2}$ nor superoxide is reactive enough to provoke oxidation. The accumulation of carbonyls in the shoot of all potato clones studied indicates that the quantity of radicals generated exceeded the capacity of the antioxidant defensive system, whereas in roots of the Al-tolerant clones, ROS were eliminated by plant defenses more efficiently. Interestingly, Boscolo et al. (2003) found that the onset of protein oxidation in two inbred lines of maize took place after the reduction of RRG observed in the sensitive line, indicating that oxidative stress is not the primary cause of root growth inhibition. In addition, the presence of $\mathrm{Al}$ did not induce lipid peroxidation in either line, contrasting with the observations made in other species. In order to characterize four potato clones for their Al sensitivity in hydroponics, using root elongation, Al-induced callose formation and $\mathrm{Al}$ concentrations of root tips as parameters, Schmohl et al. (2000) found that the higher genotypic $\mathrm{Al}$ sensitivity was related to enhanced $\mathrm{Al}$ accumulation in root tips, and that the transgenic potato mutant that overexpressed pectin methylesterase proved to be more Al-sensitive than the wild type. These data clearly demonstrate the importance of apoplast 
properties for the expression of Al-toxicity.

Although the potato is a commercially important plant, there is not much knowledge about its Al stress tolerance and the physiological consequences of this stress. Thus, the finding that Solanum species possess genetic differences in abiotic stress resistance shows that it is good plant material for studying other aspects of abiotic stress resistance mechanisms. Based on the present work, it can be suggested that toxic concentrations of Al cause oxidative stress, as evidenced by increased $\mathrm{H}_{2} \mathrm{O}_{2}$ formation, lipid peroxidation and oxidation of proteins in roots and shoot of plants, mainly in Al-sensitive clones. In this study, a significant reduction in different parameters such as length of shoot and roots, chlorophyll and carotenoid concentrations coupled with lipid peroxidation and protein oxidation indicated that high Al levels in nutrient solution produced toxic effects. It was proposed that the reduced growth in Al-sensitive clones of potato exposed to toxic levels of $\mathrm{Al}$ might be induced by an enhanced production of toxic oxygen species and subsequent lipid peroxidation. Moreover, it was possible to observe that Altolerant plants developed some defense mechanisms against oxidative stress. Further studies are required to investigate whether the oxidative stress caused by $\mathrm{Al}$ toxic levels is an early symptom that can trigger root growth inhibition.

Acknowledgements: The authors thank the Coordenação e Aperfeiçoamento de Pessoal de Nível Superior, Conselho Nacional de Desenvolvimento Científico e Tecnológico, and Fundação de Amparo à Pesquisa de Estado do Rio Grande do Sul for the research fellowships.

\section{REFERENCES}

Aebi H (1984) Catalase in vitro. Meth. Enzymol. 105:121126.

Allen RD (1995) Dissection of oxidative stress tolerance using transgenic plants. Plant Physiol. 107:1049-1054.

Arnon DI (1949) Copper enzymes in isolated chloroplasts: polyphenoloxidase in Beta vulgaris. Plant Physiol. 24:1-15.

Basu U, Good AG, Taylor GJ (2001) Transgenic Brassica napus plants overexpressing aluminium-induced mitochondrial manganese superoxide dismutase cDNA are resistant to aluminium. Plant Cell Environ. 24:12691278.

Bisognin DA, Douches DS, Buszka L, Bryan G, Wang D (2005) Mapping late blight resistance in Solanum microdontum Bitter. Crop Sci. 45:340-345.

Blokhina O, Virolainen E, Fagerstedt KV (2003) Antioxidants, oxidative damage and oxygen deprivation stress: a review. Ann. Bot. 91:179-194.

Boscolo PRS, Menossi M, Jorge RA (2003) Aluminuminduced oxidative stress in maize. Phytochemistry 62:181-189.

Bradford MM (1976) A rapid and sensitive method for the quantitation of microgram quantity of protein utilizing the principle of protein-dye binding. Anal. Biochem. 72:248-254.

Brondani C, Paiva E (1996) Análise de RFLP da tolerância à toxidez do alumínio no cromossomo 2 do milho. Pesq. Agropec. Bras. 31:575-579.

Cakmak I, Horst WJ (1991) Effect of aluminum on lipid peroxidation, superoxide dismutase, catalase, and peroxidase activities in root tip of soybean (Glycine max L.). Physiol. Plant. 83:463-468.

Collet L, Horst WJ (2001) Characterization of maize cultivars in their adaptation to acid soils on the single plant level. In: Horst WJ, Burket A, Schenk MK (eds), Plant Nutrition - Food Security and Sustainability of Agro-Ecosystems, pp.86-87. Kluwer Academic Publishers, Dordrecht.

Darkó E, Ambrus H, Stefanovits-Bányai E, Fodor J, Bakos F, Barnabás B (2004) Aluminium toxicity, Al tolerance and oxidative stress in an Al-sensitive wheat genotype and in Al-tolerant lines developed by in vitro microspore selection. Plant Sci. 166:583-591.

Degenhardt J, Larsen PB, Stephen H, Kochian LV (1998) Aluminum resistance in the Arabidopsis mutant Alr104 is caused by an aluminum-induced increase in rhizosphere pH. Plant Physiol. 117:19-27.

Dipierro N, Mondelli D, Paciolla C, Brunetti G, Dipierro S (2005) Changes in the ascorbate system in the response of pumpkin (Cucurbita pepo L.) roots to aluminium stress. J. Plant Physiol. 162:529-536.

Dong B, Sang WL, Jiang X, Zhou JM, Kong FX, Hu W, Wang LS (2002) Effects of aluminum on physiological metabolism and antioxidant system of wheat (Triticum aestivum L.). Chemosphere 47:87-92. 
El-Moshaty FIB, Pike SM, Novacky AJ, Sehgal OP (1993) Lipid peroxidation and superoxide production in cowpea (Vigna unguiculata) leaves infected with tobacco ringspot virus or southern bean mosaic virus. Physiol. Mol. Plant Pathol. 43:109-119.

Ezaki B, Gardner RC, Ezaki Y, Matsumoto H (2000) Expression of aluminum-induced genes in transgenic Arabidopsis plants can ameliorate aluminum stress and/or oxidative stress. Plant Physiol. 122:657-665.

Halliwell B, Gutteridge JMC (1999) Free Radicals in Biology and Medicine. $3^{\text {rd }}$ ed. Clarendon Press, Oxford. Hiscox JD, Israelstam GF (1979) A method for the extraction of chlorophyll from leaf tissue without maceration. Can. J. Bot. 57:1132-1334.

Ikegawa H, Yamamoto Y, Matsumoto H (2000) Responses to aluminum of suspension-cultured tobacco cells in a simple calcium solution. Soil Sci. Plant Nutr. 46:503514.

Jorge RA, Menossi M, Arruda P (2001) Probing the role of calmodulin in $\mathrm{Al}$ toxicity in maize. Phytochemistry 58:415-422.

Kochian LV (1995) Cellular mechanisms of aluminum toxicity and resistance in plants. Annu. Rev. Plant Physiol. Plant Mol. Biol. 46:237-260.

Larson RA (1988) The antioxidants of higher plants. Phytochemistry 27:969-978.

Lazof DB, Goldsmith JG, Rufty TW, Linton RW (1994) Rapid uptake of aluminum into cells of soybean root tips. Plant Physiol. 106:1107-1114.

Lawlor DW (2001) Photosynthesis. $3^{\text {rd }}$ ed. Bios Scientific Publishers, Oxford.

Levine RL, Garland D, Oliver CN, Amici A, Climent I, Lenz AG, Ahn BW, Shaltiel S, Stadtman ER (1990) Determination of carbonyl content in oxidatively modified proteins. Meth. Enzymol. 186:464-478.

Li PH, Fennell A (1985) Potato Frost Hardiness. In: Li PH (ed), Potato Physiology, pp.457-479. Academic Press, Orlando.

Lidon FC, Barreiro MG, Ramalho JC, Lauriano JA (1999) Effects of aluminum toxicity on nutrient accumulation in maize shoots: implications on photosynthesis. J. Plant Nutr. 22:397-416.

Loreto F, Velikova V (2001) Isoprene produced by leaves protects the photosynthetic apparatus against ozone damage, quenches ozone products, and reduces lipid peroxidation of cellular membranes. Plant Physiol.

\section{7:1781-1787.}

Ma JF, Ryan PR, Delhaize E (2001) Aluminum tolerance in plants and the complexing role of organic acids. Trends Plant Sci. 6:273-278.

Marschner H (1991) Mechanism of adaptation of plants to acid soils. Plant Soil 134:1-20.

Meriga B, Reddy BK, Rao KR, Reddy LA, Kishor PBK (2004) Aluminum-induced production of oxygen radicals, lipid peroxidation and DNA damage in seedlings of rice (Oryza sativa). J. Plant Physiol. 161:63-68.

Murashige T, Skoog F (1962) A revised medium for rapid growth and bioassays with tobacco tissue culture. Plant Physiol. 15:473-497.

Parker DR, Kinraide TB, Zelazny LW (1988) Aluminum speciation and phytotoxicity in dilute hydroxyaluminum solutions. Soil Sci. Soc. Am. J. 52:438-444.

Pereira LB, Tabaldi LA, Gonçalves JF, Jucoski JO, Pauletto MM, Weis SN, Nicoloso FT, Borher D, Rocha JBT, Schetinger MRC (2006) Effect of aluminum on daminolevulinic acid dehydratase (ALA-D) and the development of cucumber (Cucumis sativus). Environ. Exp. Bot. 57:106-115.

Richards KD, Schott EJ, Sharma YK, Davies KR, Gardner RC (1998) Aluminum induces oxidative stress genes in Arabidopsis thaliana. Plant Physiol. 116:409-418.

Ryan PR, DiTomaso JM, Kochian LV (1993) Aluminum toxicity in roots: an investigation of spatial sensitivity and the role of the root cap. J. Exp. Bot. 44:437-446.

Schmohl N, Pilling J, Fisahn J, Horst WJ (2000) Pectin methylesterase modulates aluminium sensitivity in Zea mays and Solanum tuberosum. Physiol. Plant. 109:419427.

Schützendübel A, Polle A (2002) Plant responses to abiotic stresses: heavy metal-induced oxidative stress and protection by mycorrhization. J. Exp. Bot. 53:13511365.

Sieczka JB, Thornton RE (1993) Commercial Potato Production in North America. Potato Association of America Handbook. Potato Assoc. of America, Orono.

Shi Q, Zhu Z, Xu M, Qian Q, Yu J (2006) Effect of excess manganese on the antioxidant system in Cucumis sativus L. under two light intensities. Environ. Exp. Bot. 58:197-205.

Simonovicová M, Huttová J, Siroká B, Tamás L (2004) Root growth inhibition by aluminum is probably 
caused by cell death due to peroxidase-mediated hydrogen peroxide production. Protoplasma 224:91-98. Snowden KC, Gardner RC (1993) Five genes induced by aluminum in wheat (Triticum aestivum) roots. Plant Physiol. 103:855-861.

Tamás L, Simonovicová M, Huttová J, Mistrík I (2004)
Aluminium stimulated hydrogen peroxide production of germinating barley seeds. Environ. Exp. Bot. 51:281-288. Yamamoto Y, Kobayashi Y, Matsumoto H (2001) Lipid peroxidation is an early symptom triggered by aluminum, but not the primary cause of elongation inhibition in pea roots. Plant Physiol. 125:199-208. 